\title{
BRIEF NOTES
}

\section{Change in Expression of the Actin Gene Family during Early Sea Urchin Development}

\author{
Glenn T. Merlino, ${ }^{1}$ Robert D. Water, Gordon P. MoOre, and Lewis J. Kleinsmith ${ }^{2}$ \\ Division of Biological Sciences, The University of Michigan, Ann Arbor, Michigan 48109
}

Received November 14, 1980; accepted in revised form February 9, 1981

\begin{abstract}
Expression of the actin gene family was studied during early sea urchin development using in vitro translation and nucleic acid hybridization techniques. Poly $(\mathrm{A})^{+}$RNA from four-cell and gastrula-stage $S$. purpuratus embryos was translated in vitro and the translation products were monitored for the presence of actin. In addition, $\operatorname{poly}(\mathrm{A})^{+}$and total RNA were prepared from various stages of development, electrophoresed on agarose gels, transferred to diazobenzyloxymethyl paper, and then hybridized with a cloned actin cDNA probe. Results of these experiments indicate that there is a sharp increase in the level of RNA coding for actin during early development, and that there are two forms of actin specific RNA exhibiting different patterns of control.
\end{abstract}

\section{INTRODUCTION}

Actin, a highly abundant protein in most eucaryotic cell types, has important functions with respect to cell shape and motility (reviewed by Pollard and Weiling, 1974; Lazarides and Revel, 1979). Genes coding for actin have been cloned and studied in many systems including yeast, slime mold, chicken, Oxytrich a follax, Drosophila, and sea urchins (summarized by Durica et al., 1980; Overbeek et al., 1981). All these organisms, with the exception of yeast, possess families of distinct but related actin genes. The size of these gene families varies from about 3 in Oxytricha to greater than 15 in Dictyostelium. Expression of the actin gene family has been studied both at the protein (e.g., Devlin and Emerson, 1980) and RNA levels (e.g., Storti et al., 1978; Margolskee and Lodish, 1980).

The role of actin during development, where cell types continuously reorient themselves during morphogenesis, is of particular interest. Actin production is almost certainly carefully regulated throughout early embryogenesis. In the mouse embryo, for example, actin synthesis is selectively stimulated during early development (Abreu and Brinster, 1978). The sea urchin represents a model developmental system whose general properties have been extensively described. In Strongylocentrotus purpuratus, the actin coding gene family consists of from 5 to 10 genes, some of which reside near each other in the genome (Durica et al., 1980; Overbeek et al., 1981). A minimum of three actinlike protein spots can be identified on two-dimensional gels (Merlino et al., 1980). In this report we present data

\footnotetext{
${ }^{1}$ G. T. Merlino's present address is Laboratory of Molecular Biology, National Cancer Institute, Bethesda, Md. 20205.

${ }_{2}^{2}$ To whom reprint requests should be addressed.
}

which indicate that the level of RNA coding for actin, while very low in oocytes and early cleavage stages, increases sharply between 12 and $24 \mathrm{hr}$ after fertilization. We discuss possible implications of these results with respect to the regulation of actin gene expression during development.

\section{MATERIALS AND METHODS}

\section{(1) Cloning and Labeling of cDNA Coding for Actin}

cDNA was synthesized using reverse transcriptase with blastula poly $(\mathrm{A})^{+}$polysomal RNA as template. The cDNA was rendered double stranded and cloned in the plasmid pBR322 by addition of synthetic Bam H1 linkers as fully described by Merlino et al. (1980). One clone, pSA38, was identified as coding for actin by several criteria, including "positive hybridization/translation" (Harpold et al., 1978). pSA38 plasmid DNA was prepared as described by El-Gewely and Helling (1980) and ${ }^{32} \mathrm{P}$ labeled by the nick-translation method of Rigby $e t$ al. (1977). Specific activity was $\sim 1 \times 10^{8} \mathrm{cpm} / \mu \mathrm{g}$.

\section{(2) Preparation of Total and Poly $(A)^{+} R N A$ from Embryos}

Oocytes of Strongylocentrotus purpuratus were fertilized in vitro and embryos were cultured using standard techniques. Total RNA was prepared by solubilization of tissue in $8 M$ guanidine- $\mathrm{HCl}$, and specific precipitation of RNA in $0.5 \mathrm{vol}$ of ethanol, according to the method of Adams et al. (1977). Poly (A) ${ }^{+}$RNA was isolated from embryos by phenol/chloroform/isoamyl alcohol extraction and oligo(dT) affinity chromatography, as previously described (Merlino et al., 1978). For preparation of polysomal poly $(\mathrm{A})^{+} \mathrm{RNA}$, polysomes 
were isolated by centrifugation through $40 \%$ sucrose, disrupted in SDS-EDTA, and then subjected to two rounds of oligo(dT) affinity chromatography (Merlino et al., 1980).

\section{(3) Translation of Poly $(A)^{+} R N A$ in Wheat Germ System}

A wheat germ S-30 fraction was prepared and used according to a modification of the procedure of Roberts and Patersen (1973), as detailed previously (Merlino et al., 1978). Radioactive proteins made from specific RNA templates were electrophoresed on an SDS-9\% polyacrylamide slab gel $(28 \times 15 \times .15 \mathrm{~cm})$ according to the method of LeStourgeon and Rusch (1973). The template activity of RNA prepared from 4 and $48 \mathrm{hr}$ embryos (Fig. 1) was similar, as measured by incorporation of radioactivity into protein. After electrophoresis, the gel was stained with Coomassie brilliant blue, destained, dried, and exposed to Kodak X-Omat X-ray film to visualize radioactive polypeptides.

\section{(4) Northern-Blot Hybridization}

RNAs (5- $\mu$ g samples) were lyophilized and dissolved in $10 \mu \mathrm{l}$ of a mixture containing $10 \mu \mathrm{l} 100 \mathrm{mM}$ Na phosphate (pH 6.6), $15 \mu \mathrm{l} 40 \%$ deionized glyoxal (Fischer), $50 \mu$ deionized DMSO, and $24 \mu$ l autoclaved water. After heating at $48^{\circ} \mathrm{C}$ for $30 \mathrm{~min}$ the RNAs were electrophoresed on a horizontal $1 \%$ agarose slab gel in $10 \mathrm{mM} \mathrm{Na}$ phosphate (pH 6.6) at $100 \mathrm{~V}$ for $2.5 \mathrm{hr}$, then transferred to diazobenzyloxymethyl (DBM) paper by the procedure of Alwine et al. (1977). The blot was incubated in 5x SSC, $50 \%$ formamide, $1 \times$ Denhardt's, $0.1 \%$ SDS, and $8 \times 10^{7} \mathrm{cpm}\left[{ }^{32} \mathrm{P}\right] \mathrm{pSA} 38$ labeled as described above, for $40 \mathrm{hr}$ at $42^{\circ} \mathrm{C}$. The paper was washed with six changes of $5 \times \mathrm{SSC}, 50 \%$ formamide at $42^{\circ} \mathrm{C}$ for $3-4 \mathrm{hr}$, then with $2 \times$ SSC to remove the formamide, and fluorographed. Bands found in the resulting fluorographs were quantitated by determination of the area under microdensitometric curves using a Numonics planimeter.

\section{RESULTS}

In order to study expression of the actin gene family during development, poly $(\mathrm{A})^{+}$RNA was prepared from four-cell and gastrula-stage $S$. purpuratus embryos and translated in vitro in a wheat germ cell-free protein synthesizing system. The resulting proteins were displayed on an SDS-acrylamide gel as shown in Fig. 1. Poly $(\mathrm{A})^{+} \mathrm{RNA}$ isolated from gastrula stage embryos is capable of directing synthesis of actin, whereas little, if any, actin is synthesized by four-cell poly $(\mathrm{A})^{+} \mathrm{RNA}$. The actin band in these experiments was identified by
FIG, 1. Developmental changes in translatable actin mRNA. poly $(A)^{+}$ RNAs were isolated from different developmental stages as described under Materials and Methods. The RNAs were translated in a wheat germ cell-free protein-synthesizing system, and the resulting ${ }^{35}$ S $]$ methionine-labeled polypeptides were displayed on a SDS-9\% polyacrylamide gel. (a), in vitro translation products from four-cell embryos (3-4 hr of development); (b), in vitro translation products from gastrula embryos (48-50 $\mathrm{hr}$ of development).

its molecular weight, isoelectric point, and its ability to bind to a DNase 1 affinity column (Merlino et al., $1979 ; 1980$ ).

The above translation experiment suggests that the level of actin message increases during development. However, an alternative interpretation of the results is that the translational efficiency of cytoplasmic actin message increases as differentiation proceeds. In order to distinguish between these possibilities, total poly $(\mathrm{A})^{+}$ RNA from 3-, 23-, and 46-hr embryos was isolated, denatured, electrophoresed on an agarose gel, transferred to DBM paper, and hybridized with a previously characterized actin cDNA clone (Fig. 2 ). In lane $a^{\prime}, \operatorname{poly}(\mathrm{A})^{+}$ RNA from 3-hr embryos is seen to hybridize very weakly to the actin cDNA probe. Lane $e^{\prime}$ is an overexposure of lane $a^{\prime}$ which shows that the small amount of actin message migrates with an apparent size of about $2.3 \mathrm{~kb}$. Both 23- and 46-hr embryo poly (A) ${ }^{+}$RNAs hybridize intensely with the actin probe, confirming that the level of actin specific RNA increases during development. Two bands are visible, indicating the presence of actin specific RNAs of 2.3 and $2.0 \mathrm{~kb}$. These sizes were calculated based on the electrophoretic mobility of the actin specific bands relative to that of a HindIII cut $\lambda$ DNA standard. When blastula polysomal poly $(A)^{+}$ RNA was analyzed by this method, both RNA species were found to be associated with polysomes, suggesting that they represent mature messenger RNAs (Fig. 2, lane $d^{\prime}$ ).

To eliminate the possibility that the apparent difference in actin gene expression during development is due to variation in the extent of RNA polyadenylation, and to more accurately assess the onset of transcript appearance, total RNA was prepared from sea urchin embryos of seven developmental stages. This RNA was 


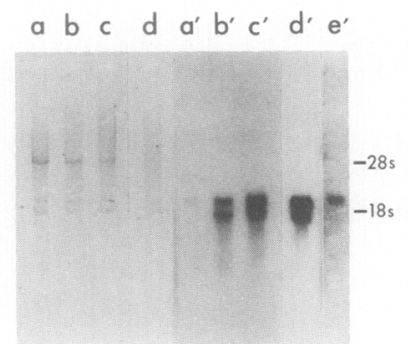

FIG. 2. Developmental changes in actin specific poly $(A)^{+}$RNA sequences. Poly $(\mathrm{A})^{+}$RNAs were isolated from various developmental stages as described under Materials and Methods. Five micrograms of RNA from each stage were denatured with glyoxal, electrophoresed on $1 \%$ agarose, and transferred to DBM paper. Actin specific sequences were visualized by hybridization to $\left[{ }^{32} \mathrm{P}\right] \mathrm{pSA} 38$, an actin specific cDNA clone. (a-d) Agarose gel stained with ethidium bromide showing the endogenous 28 and $18 \mathrm{~S}$ sea urchin rRNAs. The band appearing between the 18 and $28 \mathrm{~S}$ rRNA bands is a $28 \mathrm{~S}$ rRNA breakdown product. $\left(\mathrm{a}^{\prime}-\mathrm{e}^{\prime}\right)$ Fluorogram of the corresponding blot after hybridization to pSA38. (a, $\left.a^{\prime}\right)$ Fractionated poly $(A)^{+}$RNA from 3-hr embryos; ( $b, b^{\prime}$ ) from 23-hr embryos; (c, $c^{\prime}$ ) from 46-hr embryos; $\left(d, d^{\prime}\right)$ fractionated polysomal poly $(A)^{+}$RNA from blastula $27-\mathrm{hr}$ embryos; $\left(\mathrm{e}^{\prime}\right)$ overexposure of lane $\mathrm{a}^{\prime}$ to visualize the faint band.

subjected to Northern analysis as before (Fig. 3). RNA prepared from egg, 4- and 12-hr embryos shows little hybridization with the actin cDNA probe. RNA from

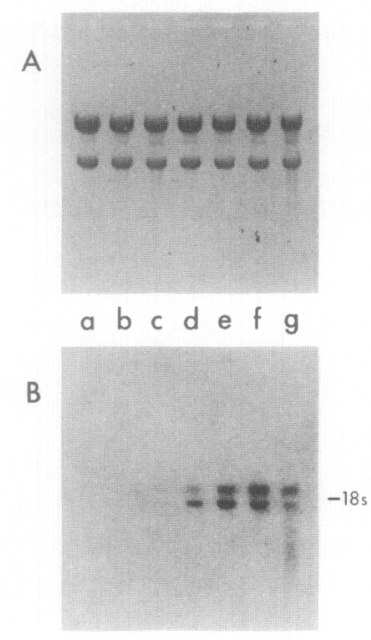

Fig. 3. Developmental changes in actin specific total RNA sequences. Total RNAs were isolated from various embryonic stages by use of $8 \mathrm{M}$ guanidine- $\mathrm{HCl}$. Five micrograms of RNA from each stage were denatured with glyoxal, electrophoresed on $1 \%$ agarose, and transferred to DBM paper. Actin specific RNAs were visualized by hybridization to $\left[{ }^{32} \mathrm{P}\right] \mathrm{pSA} 38$, an actin specific cDNA clone. (A) agarose gel stained with ethidium bromide showing the endogenous 28 and $18 \mathrm{~S}$ sea urchin rRNAs. The $5 \mathrm{~S}$ rRNA bands are faint because small $\mathrm{RNAs}$ are selectively lost during guanidine- $\mathrm{HCl}$ preparation of the RNA. (B) fluorogram of the corresponding blot after hybridization to pSA38. RNA from (a) oocyte; (b) 4-hr embryos; (c) 12-hr embryos, (d) 18-hr embryos; (e) 24-hr embryos; (f) 36-hr embryos; (g) 48-hr embryos.
18-, 24-; 36-, and 48-hr embryos hybridizes much more intensely to the probe, indicating that the level of actin specific RNA increases dramatically between 12 and 24 $\mathrm{hr}$ after fertilization. Two actin specific RNAs of 2.3 and $2.0 \mathrm{~kb}$ are again detected.

The bands in the Northern blots of Figs. 2 and 3 were quantitated relative to each other by microdensitometric scanning of the autoradiograms (Table 1). The results indicate that the two actin specific RNA transcripts are not regulated in concert. In both the poly $(\mathrm{A})^{+}$ and total RNA samples, the larger actin specific transcript is most highly expressed early in development, by $18-24 \mathrm{hr}$ the smaller transcript predominates, and by $46-48 \mathrm{hr}$ the larger species is again more prevalent. Relative to the small amount of actin specific RNA present in the oocyte, the 2.3-kb RNA species increases about 23-fold in total RNA with a peak at $36 \mathrm{hr}$. The 2.0 -kb species increases about 115 -fold with a peak at $24 \mathrm{hr}$.

\section{DISCUSSION}

It is apparent from the in vitro translation data of Fig. 1, as well as the Northern blots shown in Figs. 2 and 3 , that the level of actin message changes dramatically between early cleavage and blastulation in sea urchin embryos. In earlier experiments, we observed a concomitant increase in the rate of actin protein synthesis (Merlino et al., 1979). The molecular mechanism responsible for this change is unknown, and a wide variety of explanations are possible. The large extent of

TABLE 1

Relative Level of Actin Specific Sequences in Total AND POLY $(A)^{\dagger}$ RNa Throughout Early SEa URChIN DEVElopment

\begin{tabular}{lccc}
\hline RNA Source & $\begin{array}{c}\text { hr of } \\
\text { Development }\end{array}$ & $\begin{array}{c}\text { Level of } \\
\text { 2.3-kb-RNA } \\
\text { species }^{\prime \prime}\end{array}$ & $\begin{array}{c}\text { Level of 2.0- } \\
\text { kb-RNA } \\
\text { species }\end{array}$ \\
\hline Poly(A) RNA & 3 & 1.0 & 0.1 \\
Poly(A) ${ }^{+}$RNA & 23 & 6.9 & 8.8 \\
Poly(A) RNA & 46 & 16.6 & 11.3 \\
Total RNA & Ooycte & 0.3 & 0.1 \\
Total RNA & 4 & 0.7 & 0.1 \\
Total RNA & 12 & 0.7 & 0.5 \\
Total RNA & 18 & 2.1 & 3.9 \\
Total RNA & 24 & 5.5 & 11.5 \\
Total RNA & 36 & 6.9 & 9.7 \\
Total RNA & 48 & 4.3 & 3.3 \\
\hline
\end{tabular}

"The data were generated by microdensitometric scan of the autoradiograms shown in Figs. 2 and 3. The numbers indicate the relative amount of actin specific RNA wherein the level of the 2.3-kb species from poly $(\mathrm{A})^{+} \mathrm{RNA}$ of $3 \mathrm{hr}$ embryos has been arbitrarily assigned a value of " 1 " simply to form a convenient basis for comparison. Values lower than 1 are subject to considerable inaccuracy due to the difficulty of scanning low intensity bands. 
overlap in nuclear RNA complexity between developmental stages and adult sea urchin tissues observed by Wold et al. (1978) led to skepticism that transcriptionlevel control operates to selectively induce distinct gene sets in differentiating tissues. However, some highly prevalent proteins do appear to be transcriptionally regulated (Davidson and Britten, 1979), and actin may be in this category. Expression of the actin gene family during development is clearly unusual since in contrast to the present results observed for actin, transcripts coding for most prevalent proteins are stored in the egg in relatively large quantities (Lasky et al., 1980).

The two actin specific RNA bands seen on the Northern blots may represent messages coding for different forms of actin. Alternatively, a precursor/product relationship may exist between the two. The finding that both RNA species are associated with polysomes suggests that they are, in fact, functional mature mRNAs. Further work is needed to determine if they actually code for the multiple forms of actin seen earlier on two dimensional gels (Merlino et al., 1980). It is interesting to note that the two RNAs accumulate differentially during development, as shown in Table 1 . It seems difficult to account for this apparent differential expression solely on the basis of accumulation of transcripts from constitutively transcribed structural genes. The results presented here are consistent with the concept that transcriptional and/or posttranscriptional regulatory mechanisms act to enhance the level of actin gene expression during sea urchin development.

Supported by Grant PCM 78-15300 from the National Science Foundation. G.T.M. was supported by a National Science Foundation Graduate Fellowship, and R.D.W. was supported by a Postdoctoral Fellowship from the National Institutes of Health (5F32-GM01638).

\section{REFERENCES}

Abrev, S. L., and BRINSTER, R. L. (1978). Synthesis of tubulin and actin during the preimplantation development of the mouse. Exp. Cell. Res. 114, 135-141.

Adams, S. L., Sobel, M. E., Howard, B. H., Olden, N., Yamada, K. M., DECROMBRUGghe, B., and PASTAN, I. (1977). Levels of translatable mKNAs for cell surface protein, collagen precursors and two membrane proteins are altered in Rous sarcoma virus-transformed chick embryo fibroblasts. Proc. Nat. Acad. Sci. USA 74, 3399-3404.

Alwine, J. C.,Kemp, D. J., and STARK, G. R. (1977). Method for detection of specific RNAs in agarose gels by transfer to diazobenzyloxymethyl-paper and hybridization with DNA probes. Proc. Nat. Acad. Sci. USA 74, 5350-5354.

DAvidson, E. H., and BRITTEN, R. J. (1979). Regulation of gene expression: Possible role of repetitive sequences. Science 204, 1052-1059.
Devlin, R. B., and Emerson, C. P. (1978). Coordinate regulation of contractile protein synthesis during myoblast differentiation. Cell 13, 599-611.

Durica, D. S., Schloss, J. A., and Crain, W. R. (1980). Studies on the organization of actin gene sequences in the sea urchin: Molecular cloning of an intron-containing DNA sequence coding for a cytoplasmic actin. Proc. Nat. Acad. Sci. USA 77, 5683-5687.

El-Gewely, M. R., and HELling, R. B. (1980). Preparative separation of DNA-ethidium bromide complexes by zonal density gradient centrifugation. Anal. Biochem. 102, 423-428.

HARPold, M. M., DoBner, P. R., Evans, R. M., and BANCRofT, F. C. (1978). Construction and identification by positive hybridizationtranslation of a bacterial plasmid containing a rat growth hormone structural gene sequence. Nucl. Acid Res. 6, 2039-2053.

LASKY, L. A., LEV., Z., JI-Hou XIN, BRITTEN, R. J., and DAvidSON, E. H. (1980). Messenger RNA prevalence in sea urchin embryos measured with cloned cDNAs. Proc. Nat. Acad. Sci. USA 77, 53175321.

LAZARIDES, E., and Revel, J. P. (1979). The molecular basis of cell movement. Sci. Amer. 240(No. 5), 110-113.

LeStourgeon, W. M., and RUSCH, H. P. (1973). Localization of nucleolar and chromatin residual acidic protein changes during differentiation in Physarum polycephalum. Arch. Biochem. Biophys. $155,144-158$.

MARGOLSKEE, J. P., and LODISH, H. R. (1980). The regulation of the synthesis of actin and two other proteins induced early in Dictyosteliuum discoideum development. Develop. Biol. 74, 50-64.

Merlino, G. T., Chamberlain, J. P., and Kleinsmith, L. J. (1978). Effects of deciliation on tubulin messenger RNA activity in sea urchin embryos. J. Biol. Chem. 253, 7078-7085.

Merlino, G. T., Water, R. D., Chamberlain, J. P., Jackson, D. A. El-Gewely, R. A., and Kleinsmith, L. J. (1980). Cloning of sea urchin actin gene sequences for use in studying the regulation of actin gene transcription. Proc. Nat. Acad. Sci. USA 77, 765-769.

Merlino, G., Water, R., Chamberlain, J., El-Gewely, R., Helling, $R$., and KLEINSMITH, L. (1979). Isolation of recombinant DNA containing putative sea urchin actin gene sequences. 11th International Congress Biochemistry. National Research Council Canada, Ottawa. Abstract, p. 25.

Overbeek, P. A., Merlino, G. T., Peters, N. K., Cohn, V. H., Moore, G. P., and KLEINSMITH, L. J. (1981). Manuscript submitted.

POLLARD, T. D., and WeIHING, R. R. (1974). Actin and myosin and cell movement. In "Critical Review in Biochemistry, 2" (G. Fasmon, ed.), pp. 1-65. CRC Press, Cleveland, Ohio.

Rigby, P. W. J., Dieckman, B. M., Rhodes, C., and Berg, P. (1977). Labelling deoxyribonucleic acid to high specific activity in vitro by nick translation with DNA Polymerase I. J. Mol. Biol. 113, 237-251.

Roberts, B. E., and Paterson, B. M. (1973). Efficient translation of Tobacco Mosaic Virus RNA and rabbit globin in 9S RNA in cellfree system from commercial wheat germ. Proc. Nat. Acad. Sci. USA 70, 2330-2334.

Storti, R. U., Horovitch, S. J., SCOTT, M. P., RICH, A., and PARdue, M. L. (1978). Myogenesis in primary cell cultures from Drosophila melanogaster: Protein synthesis and actin heterogeneity during development. Cell 13, 589-598.

Wold, B. J., KLEIN, W. H., Hough-Evans, B. R., BRITten, R. J., and DAvidson, E. H. (1978). Sea urchin embryo mRNA sequences expressed in the nuclear RNA of adult tissue. Cell 14, 941-950. 